\title{
PENERAPAN MODEL KELOMPOK USAHA KREATIF ISLAMI (KUKIS) DALAM PEMBERDAYAAN PEREMPUAN BERBASIS PONDOK PESANTREN
}

\author{
${ }^{1)}$ Novi Widiastuti, ${ }^{2)}$ Prita Kartika \\ ${ }^{1,2)}$ Program Studi Pendidikan Luar Sekolah STKIP Siliwangi \\ 1) noviw9@gmail.com
}

\begin{abstract}
ABSTRAK
Pondok pesantren Ulul Albab Cabang Sangkanhurip Kabupaten Bandung terletak di tengah persawahan sehingga masyarakat masih kesulitan dalam mengakses program yang diselenggarakan di pondok pesantren tersebut. Kondisi masyarakat yang sangat heterogen menyebabkan sering terjadi konflik diantara masyarakat itu sendiri bahkan dengan pihak pondok pesantren. Konflik yang terjadi pada masyarakat disebabkan oleh beberapa faktor diantaranya yaitu rendahnya pendidikan, kesulitan ekonomi dan rendahnya pemahaman agama pada masyarakat. Hadirnya pondok pesantren diharapkan mampu menjadi solusi dalam mengatasi permsalahan tersebut. Selain itu, budaya rentenir masih sangat merajalela sehingga bukan hanya menambah maslaah dalam ekonomi, melainkan masyarakat terus menanggung beban dosa yang berlipat dari memakan harta riba. Melihat permasalahan tersebut, maka kami tim peneliti dan pengurus pondok pesantren merancang sebuah model pemberdayaan perempuan berbasis pondok pesantren dalam upaya meningkatkan tiga aspek kehidupan yaitu Agama, Pendidikan, dan Ekonomi (APE). Model pemberdayaan perempuan yang kami namai model Kukis ini akan diujicobakan dalam penelitian dengan tujuan untuk melihat 1) kondisi sebelum dan sesudah penerapan model kukis, 2) Hambatan yang dihadapi, serta 3) Solusi permasalahan yang muncul pada penerapan model tersebut. Penelitian ini akan menggunakan metode pra eksperimen dengan membandingkan kondisi sebelum dan sesudah penerapan model kukis dengan sasaran penelitian yaitu perempuan usia produktif di lingkungan pondok pesantren. Hasil penelitian menunjukkan bahwa terjadi Peningkatan penghasilan rata-rata sebesar $18 \%$ yaitu Rp. 255.000 per warga belajar selama 1 bulan memulai usaha menunjukkan adanya keberhasilan penerapan model Kukis meskipun belum optimal. Pemahaman warga belajar juga mengalami peningkatan rata-rata sebesar 33\%.Hambatan yang ditemukan dalam ujicoba model kukis adalah (1) Menurunnya motivasi warga belajar (2) rendahnya rasa percaya diri, (3) mental karyawan. Upaya yang dapat dilakukan untuk mengatasi hambatan dalam ujicoba model kukis yaitu : (1) Mengidentifikasi warga belajar yang siap untuk membangun usaha, (2) menjalin kerjasama dalam pemasaran.
\end{abstract}

Kata Kunci : Model Kelompok Usaha Kreatif Islami (KUKIS), Pemberdayaan Perempuan, Pondok Pesantren.

\section{PENDAHULUAN}

Pondok Pesantren Ulul Albab cabang Sangkanhurip Kabupaten Bandung mulai berdiri pada tahun 2004. Berjalan selama dua tahun dengan program rutin pengajian anak-anak dan ibuibu, sampai pada tahun 2006 pondok pesantren mendapat tanah wakaf di tengah persawahan yang belum ada akses jalan. Hal ini menyebabkan masyarakat mulai tidak aktif mengikuti program pesantren. Program yang masih bejalan hanyalah program belajar baca tulis Qur'an bagi anak-anak. 
Seiring meningkatkanya angka kelahiran, maka PAUD menjadi kebutuhan baru di masyarakat. Hal ini mendorong pengelola pondok pesantren untuk menambah program bagi anak usia dini secara gratis pada tahun 2009. Pada awalnya program ini mendapat respon yang positif dari masyarakat karena tidak memungut biaya sedikitpun. Seiring meningkatnya kebutuhan belajar, maka pondok pesantren mulai menetapkan biaya pada orang tua siswa yang sebetulnya masih sangat terjangkau oleh masyarakat namun justru menuai protes dan akhirnya program PAUD menjadi terhenti setelah dua tahun berjalan. Hal ini menunjukkan bahwa masyarakat memiliki kesadaran pendidikan yang sangat rendah.

Berbagai pendekatan dilakukan pada masyarakat, sehingga PAUD mulai aktif kembali pada tahun 2014 dan masyarakat mulai memiliki kesadaran untuk membayar biaya yang hanya untuk bahan belajar anak. Selama PAUD berjalan banyak terdengar keluhan masyarakat khususnya orang tua siswa mengenai kondisi ekonomi mereka yang banyak terlilit dengan rentenir. Hal ini menjadi sebuah indikator bahwa masyarakat mengalami ekonomi yang lemah diikuti dengan lemahnya iman, serta rendahnya pendidikan.

Kemiskinan secara umum dikategorikan menjadi empat jenis yaitu kemiskinan absolut, kemiskinan relatif, kemiskinan struktural, dan kemiskinan kultural. Keempat kategori ini merupakan masalah yang snagat urgen untuk segera dipecahkan. Salah satu strategi yang dapat dilakukan adalah melalui penguatan untuk memberdayakan, dan kegiatan pemberdayaan. Bahkan kemiskinan bisa diakibatkan oleh program pemberdayaan yang sifatnya top down dan kental akan unsur politik sebagaimana hasil penelitian yang dilakukan oleh Tobirin (2013) menyatakan bahwa proses pemberdayaan masyarakat selama ini belum dapat menyentuh permasalahan pokok yaitu peningkatan kemandirian dan kesejahteraan masyarakat. Program Pemberdayaan dalam upaya pengentasan kemiskinan dilaksanakan berbasis pada state policy, rutinitas, dan proyek. Dalam proses pendekatan struktural, perencanaan tidak melibatkan peran masyarakat dan hanya berdasarkan petunjuk teknis pelaksanaan yang birokratis. Akibatnya pemberdayaan lebih mengutamakan dimensi fisik daripada nilai kemandirian dan penguatan modal sosial. Pendekatan dan strategi pemberdayaan dianggap gagal dalam memberikan dorongan untuk mencapai kemandirian secara pribadi, kelompok dan masyarakat. Faktor penyebab kurang optimalnya pemberdayaan adalah formalitas dalam pemenuhan kebutuhan sesaat, tidak adanya dimensi ukuran pemberdayaan, simbolisasi dan politisasi pemberdayaan, rendahnya kapasitas kelembagaan, dan hilangnya pendekatan kultural. Melihat kondisi tersebut kami berharap model KUKIS ini tidak ada unsur politik dan bersifat bottom up sehingga akan mencapai pemberdayaan sesungguhnya.

Berdasarkan hasil identifikasi awal mengenai kondisi masyarakat terutama perempuan usia produktif. Diperoleh data sebagai berikut :

1. Pendidikan masyarakat $80 \%$ adalah lulusan SD, 10\% lulusan SMP, $10 \%$ lulusan SMA sehingga hal ini menunjukkan bahwa selain ekonomi, masyarakat juga tidak mengutamakan pendidikan;

2. Penghasilan keluarga rata-rata 1,5 juta per bulan dengan rata-rata tanggungan yaitu 2 anak. Hal ini sudah tentu tidak mencukupi biaya hidup;

3. Hampir $70 \%$ masyarakat terbiasa meminjam uang pada rentenir menunjukkan lemahnya pemahaman agama.

Permasalahan di atas menjadi landasan kami tim peneliti untuk merancang sebuah program inovatif yang mampu membuat perempuan lebih berdaya dan mandiri dengan menjadikan agama sebagai landasan sehingga diharapkan selain mendapatkan penghasilan tambahan, juga mendapatkan pendidikan agama dan keterampilan vokasional. Hal ini juga sejalan 
dengan tjuan peningkatan Human Development Indeks (HDI) yaitu rata-rata usia harapan hidup seseorang dihitung sejak saat kelahirannya, rata-rata tingkat pendidikan yang ditempuh oleh anak-anak dibawah usia 15 tahun dan angka melek huruf, serta kemampuan ekonomi penduduknya yang diukur dengan angka pendapatan rata-rata penduduknya.

Model Kelompok Usaha Kreatif Islami (KUKIS) ini diharapkan menjadi solusi dari permasalahan tersebut. Model KUKIS ini adalah sebuah model inovatif dalam upaya pemberdayaan perempuan melalui kelompok usaha yang terdiri para perempuan usia produktif yang memiliki keinginan untuk maju dan berkembang dari kondisi yang terpuruk menjadi lebih baik terutama dari segi ekonomi. Kelompok ini dibentuk berdasarkan minat dan kemampuan kelompok tersebut. Warga dilibatkan langsung mulai dari perencanaan, pelaksanaan dan evaluasi sehingga warga belajar berpartisipasi aktif. Kegiatan yang dilakukan dalam KUKIS ini diantaranya adalah peningkatan kognitif melalui pemaparan materi, peningkatan keterampilan melalui pelatihan kriya, dan peningkatan ekonomi melalui kegiatan praktik wirausaha.

Pemberdayaan adalah bagaimana menjadikan seseorang mampu berdiri sendiri dan bahkan membantu yang lain atau kita sering mendengar istilah helping people to help themselve artinya ketika akan memberdayakan seseorang berarti kita telah membantu seseorang untuk dapat membantu dirinya sendiri. Oleh karena itu ada beberapa tahapan dalam pemberdayaan agar terjadi perubahan yang terencana yaitu dengan beberapa langkah berikut menurut Lippit (Anwas, 2012:41) yaitu :

1. Menumbuhkan kebutuhan

2. Membangun hubungan untuk berubah

3. Melakukan hal-hal yang berkenaan dengan perubahan

4. Pemutusan hubungan

Model KUKIS ini belum pernah diujicoba sebelumnya, namun berdasarkan hasil penelitian yang dilakukan oleh Madjid dkk (2015) menyatakan bahwa adanya hubungan antara program pemberdayaan dengan kemandirian masyarakat dan secara simultan bahwa terdapat hubungan yang 'sangat kuat" antara program pemberdayaan dengan penaggulangan kemiskinan di Kota Kotamobagu. Oleh karena itu model Kukis sebagai model pemberdayaan ini diangkat dalam tema penelitian untuk menjadi bahan perbaikan model sebelumnya dan pengembangan model selanjutnya. Rumusan masalah dalam penelitian ini adalah "bagaimana penerapan model kukis dalam pemberdayaan perempuan berbasis pesantren?" dengan tujuan penelitian adalah untuk mengetahui :

1. Kondisi sebelum dan sesudah penerapan ujicoba model kukis

2. Hambatan yang ditemukan dalam ujicoba model kukis

3. Upaya yang dapat dilakukan untuk mengatasi hambatan dalam ujicoba model kukis.

Hasil ujicoba penelitian ini diharapkan menambah hasanah keilmuan pada dunia pendidikan khususnya pendidikan luar sekolah yang berkecimpung pada masyarakat secara langsung maupun tidak langsung melalui program pemberdayana masyarakat. Sehingga luaran dari penelitian ini akan diseminarkan pada seminar nasional dan akan disusun bahan ajar yang dapat digunakan pada perkuliahan khususnya di prodi pendidikan luar sekolah STKIP Siliwangi Bandung. 


\section{KAJIAN TEORI}

\section{A. Konsep Pemberdayaan Perempuan}

\section{Pengertian Pemberdayaan}

Kegiatan pengembangan masyarakat merupakan kegiatan yang bertujuan untuk mengembangkan suatu kelompok tertentu di suatu daerah. Pengembangan masyarakat tersebut biasa dikenal dengan istilah pemberdayaan (empowerment) masyarakat. Ada beberapa definisi mengenai konsep pemberdayaan. Pemberdayaan menurut arti secara bahasa adalah proses, cara, perbuatan membuat berdaya, yaitu kemampuan untuk melakukan sesuatu atau kemampuan bertindak yang berupa akal, ikhtiar atau upaya (Depdiknas, 2003). Masyarakat adalah kesatuan hidup manusia yang berinteraksi menurut suatu sistem adat istiadat tertentu yang bersifat kontinyu, dan yang terikat oleh suatu rasa identitas bersama (Koentjaraningrat, 2009). Ife (dalam Martono, 2011) mendefinisikan konsep pemberdayaan masyarakat sebagai proses menyiapkan masyarakat dengan berbagai sumber daya, kesempatan, pengetahuan, dan keahlian untuk meningkatkan kapasitas diri masyarakat di dalam menentukan masa depan mereka, serta berpartisipasi dan memengaruhi kehidupan dalam komunitas masyarakat itu sendiri. Kartasasmita (1995), mengemukakan bahwa pemberdayaan masyarakat adalah upaya untuk meningkatkan harkat dan martabat lapisan masyarakat untuk melepaskan diri dari perangkap kemiskinan dan keterbelakangan. Intinya bahwa pemberdayaan masyarakat bertujuan untuk melahirkan masyarakat yang mandiri dengan menciptakan kondisi yang memungkinkan potensi masyarakat dapat berkembang.

\section{Pengertian Pemberdayaan Perempuan}

Pemberdayaan perempuan merupakan upaya untuk mengatasi hambatan guna mencapai pemerataan atau persamaan bagi laki-laki dan perempuan pada setiap tingkat proses pembangunan. Menurut Novian (2010) pemberdayaan perempuan adalah upaya pemampuan perempuan untuk memperoleh akses dan kontrol terhadap sumber daya, ekonomi, politik, sosial, budaya, agar perempuan dapat mengatur diri dan meningkatkan rasa percaya diri untuk mampu berperan dan berpartisipasi aktif dalam memecahkan masalah, sehingga mampu membangun kemampuan dan konsep diri.

\section{Sasaran Program Pemberdayaan Perempuan}

Secara umum sasaran dari program pemberdayaan perempuan, pertama adalah meningkatnya kualitas sumber daya perempuan di berbagai kegiatan sektor dan subsektor serta lembaga dan nonlembaga yang mengutamakan peningkatan kemampuan dan profesionalisme atau keahlian kaum perempuan. Kedua, mewujudkan kepekaan, kepedulian gender dari seluruh masyarakat, penentu kebijakan, pengambil keputusan, perencana dan penegak hukum serta pembaharuan produk hukum yang bermuatan nilai sosial budaya serta keadilan yang berwawasan gender. Kemudian sasaran yang ketiga yaitu mengoptimalkan koordinasi dan keterpaduan dalam pengelolaan pemberdayaan perempuan yang meliputi aspek perencanaan, pelaksanaan, pengendalian, pemantauan, evaluasi dan pelaporan.

\section{B. Konsep Kewirausahaan}

\section{Pengertian Kewirausahaan}

Kewirausahaan (Entrepreneurship) adalah proses mengidentifikasi, mengembangkan, dan membawa visi ke dalam kehidupan. Visi tersebut bisa berupa ide inovatif, peluang, cara yang lebih baik dalam menjalankan sesuatu. Hasil akhir dari proses tersebut adalah penciptaan usaha baru yang dibentuk pada kondisi risiko atau ketidakpastian. Pendidikan kewirausahaan telah diajarkan sebagai suatu displin ilmu tersendiri yang independen. (Suryana, 2003) Hal itu menurut Soeharto Prawirokusuma (1997) dikarenakan, 
a. Kewirausahaan berisi "body of knowledge" yang utuh dan nyata (distinctive), yaitu ada teori, konsep, dan metode ilmiah yang lengkap.

b. Kewirausahaan memiliki dua konsep, yaitu posisi "venture start-up" dan "venturegrowth", ini tidak jelas masuk dalam kerangka pendidikan manajemen umum yang memisahkan antara manajemen dan kepemilikan usaha.

c. Kewirausahaan merupakan disiplin ilmu yang memiliki objek tersendiri

d. Kewirausahaan merupakan alat untuk menciptakan pemerataan berusaha dan pemerataan pendapatan. (Suryana, $2003: 8$ )

\section{Objek Studi Kewirausahaan}

Objek studi kewirausahaan adalah nilai-nilai dan kemampuan (ability) seseorang yang diwujudkan dalam bentuk perilaku. Menurut Soemahamidjaja (1997:14-15), kemampuan seseorang yang menjadi objek kewirausahaan meliputi; (Suryana, 2003: 9)

a. Kemampuan merumuskan tujuan hidup/ usaha

b. Kemampuan memotivasi diri untuk melahirkan suatu tekad kemauan yang menyala-nyala.

c. Kemampuan untuk berinisiatif

d. Kemampuan berinovasi, yang melahirkan kreativitas (daya cipta) setelah dibiasakan berulang-ulang akan melahirkan motivasi.

e. Kemampuan untuk membentuk modal uang atau barang modal

f. Kemampuan untuk mengatur waktu dan membiasakan diri untuk selalu tepat waktu dalam segala tindakan melalui kebiasaan yangselalu tidak menundak pekerjaan.

g. Kemampuan mental yang dilandasi dengan agama

h. Kemampuan untuk membiasakan diri dalam mengambil hikmah dari pengalaman yang baik maupun menyakitkan.

\section{Hakikat Kewirausahaan}

Secara sederhana arti wirausahawan (entrepreneur) adalah orang yang berjiwa berani mengambil resiko untuk membuka usaha dalam berbagai kesempatan. Berjiwa berani mengambil resiko artinya bermental mandiri dan berani memulai usaha, tanpa diliputi rasa takut atau cemas sekalipun dalam kondisi tidak pasti.

Ada dua pendapat tentang pengertian kewirausahaan, yaitu Peter F. Drucker mengatakan bahwa kewirausahaan merupakan kemampuan dalam menciptakan sesuatu yang baru dan berbeda. Pengertian ini mengandung maksud bahwa seorang wirausahawan adalah orang yang memiliki kemampuan untuk menciptakan sesuatu yang baru, atau mampu menciptakan sesuatu yang berbeda dengan sesuatu yang sudah ada sebelumnya. Sementara itu Zimmerer mengartian kewirausahaan sebagai suatu proses penerapan kreativitas dan inovasi dalam memecahkan persoalan dan menemukan peluang untuk memperbaiki kehidupan (usaha) (Kasmir, 2007: 16-19).

Dari kedua pendapat di atas dapat disimpulkan bahwa kewirausahaan merupakan suatu kemampuan dalam hal menciptakan kegiatan usaha. Seorang wirausahawan harus memilki kemampuan yang kreatif dan inovatif dalam menemukan dan menciptakan berbagai ide.

Kegiatan wirausaha dapat dijalankan sesorangatau sekelompok orang. Dengan kata lain seseorang baik secara pribadi maupun bergabung dengan orang lain dapat menjalankan kegiatan usaha atau membuka usaha. Secara pribadi artinya membuka perusahaan dengan inisiatif dan modal serang diri. Sementara itu berkelompok adalah secara bersama- sama dua orang atau lebih dengan cara masing- masing menyetor modal dalam bentuk uang atau keahliannya. Jadi, untuk berwirausaha dapat dilakukan dengan cara

a. Memiliki modal sekaligus menjadi pengelola 
b. Menyetor modal dan pengelolaan ditangani pihak mitra

c. Hanya menyerahkan tenaga namun dikonversikan ke dalam bentuk saham sebagai bukti kepemilikan usaha.

Dewasa ini belum ada terminologi yang persis sama tentang kewirausahaan. Kewirausahaan pada hakikatnya adalah sifat, ciri, dan watak seseorang yang memiliki kemauan dalam mewujudkan gagasan inovatif kedalam dunia nyata secara kreatif. Kewirausahaan merupakan gabungan dari kreativitas, keinovasian,dan keberanian menghadapi resiko yang dilakukan dengan cara kerja keras untuk membentuk dan memelihara usaha baru. Dari beberapa konsep kewirausahaan, ada enam hakikat penting kewirausahaan, yaitu:

a. Kewirausahaan adalah suatu nilai yang diwujudkan dalam perilaku yang dijadikan dasar sumber daya, tenaga penggerak, tujuan, siasat, kiat, proses, dan hasil bisnis (Ahmad Sanusi, 1994).

b. Kewirausahaan adalah suatu kemampuan untuk menciptakan sesuatu yang baru dan berbeda (Drucker, 1959).

c. Kewirausahaan adalah suatu proses penerapan kreativitas dan keinovasian dalam memecahkan persoalan dan menemukan peluang untuk memperbaiki kehidupan (usaha) (Zimmerer,1996).

d. Kewirausahaan adalah suatu nilai yang diperlukan untuk memulai suatu usaha (start-up phase) dan perkembangan usaha (verture growth) (Soeharto Prawiro, 1997)

e. Kewirausahaan adalah suatu proses dalam mengerjakan sesuatu yang baru (creative), dan sesuatu yang berbeda (innovative) yang bermanfaat memberikan nilai lebih.

f. Kewirausahaan adalah usaha menciptakan nilai tambah dengan jalan mengkombinasikan sumber-sumber melalui cara-cara baru dan berbeda untuk memenangkan persaingan.

Berdasarkan keenam konsep di atas, secara ringkas kewirausahaan dapat definisikan sebagai suatu kemampuan kreatif dan inovatif yang dijadikan kiat, dasar, sumber daya, proses, dan perjuangan untuk menciptakan nilai tambah barang dan jasa yang dilakukan dengan keberanian untuk menghadapi resiko.

\section{Karakteristik Kewirausahaan}

Banyak para ahli yang mengemukakan karakteristik kewirausahaan dengan berbagai konsep yang berbeda-beda. Dalam Islam karakteristik wirausaha antara lain (Alma Buchari, 2006) :

a. Sifat takwa, tawakkal, zikir dan syukur.

b. Jujur.

c. Bangun Subuh dan bekerja.

d. Toleransi.

e. Berzakat dan berinfaq.

\section{HASIL DAN PEMBAHASAN}

\section{Kondisi sebelum dan sesudah penerapan ujicoba model kukis}

a. Hasil Pretest dan Postest 


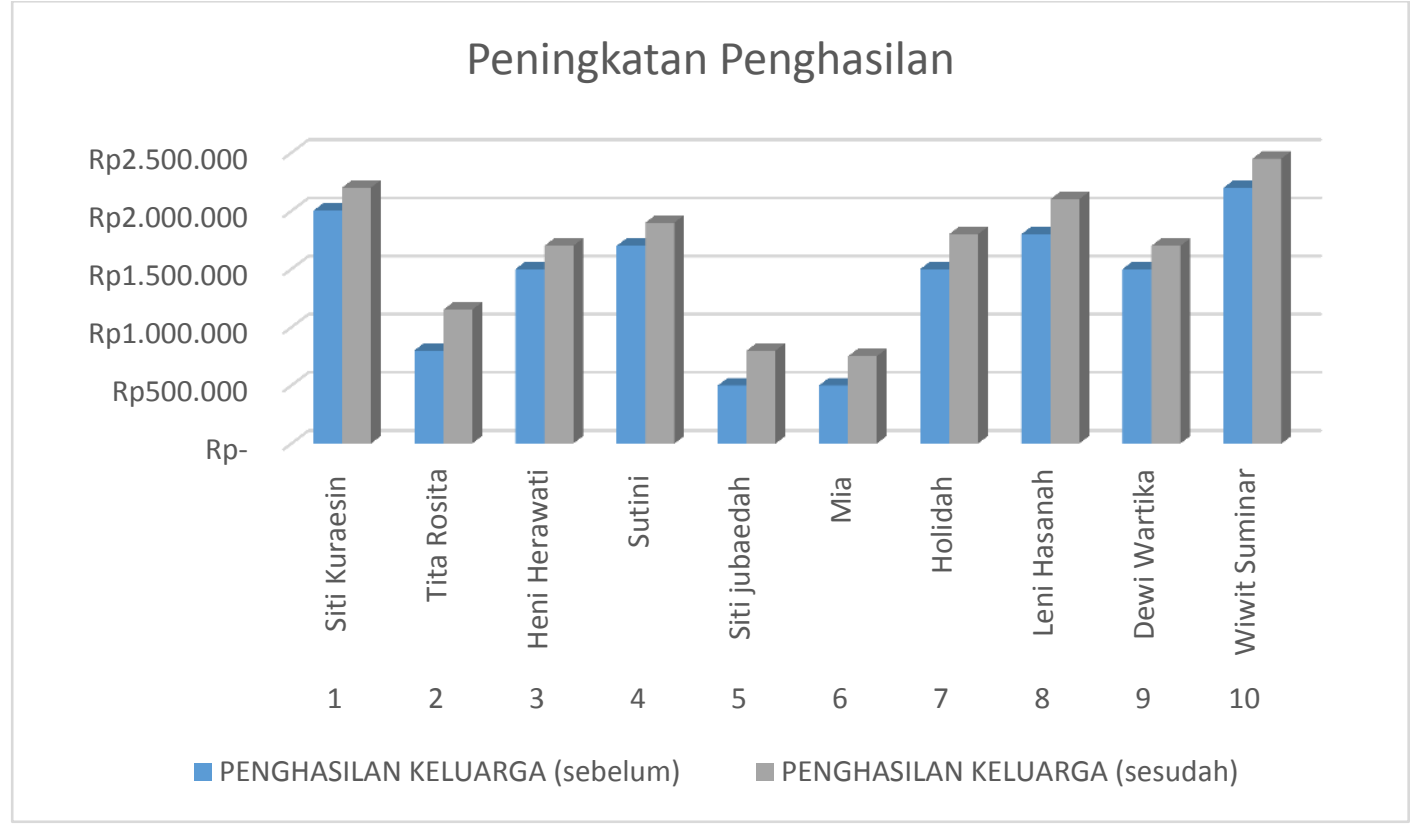

Gambar 1. Peningkatan Penghasilan Warga Belajar

Terlihat adanya peningkatan penghasilan meskipun belum begitu signifikan. Namun ini adalah awal yang cukup baik. Jumlah warga belajar yang komitmen hanya 10 orang dikarenakan berbagai faktor. Kenaikan penghasilan rata-rata sebesar Rp. 255.000 per orang. Penghasilan ini diperoleh dari penjualan produk yang dikoordinir maupun mandiri. Pendapatan tambahan ini menjadi tambahan motivasi bagi warga belajar untuk terus menjalani usaha yang dibangun oleh kelompok ini.

Penghasilan ini diperoleh dari penjualan aksesoris dan penjualan snack selama 1 bulan. Penjualan lebih tinggi pada snack dikarenakan bisnis makanan lebih cepat perputarannya dibandingkan dengan bisnis aksesoris. Pemasarana dilakukan secara online maupun offline. Online melalui Instagram, FB, dan Whatsapp dibantu oleh mahasiswa dan pengelola pesantren. Secara offline dengan menawarkan langsung pada tetangga maupun teman-teman serta sistem konsinyasi dengan warung.

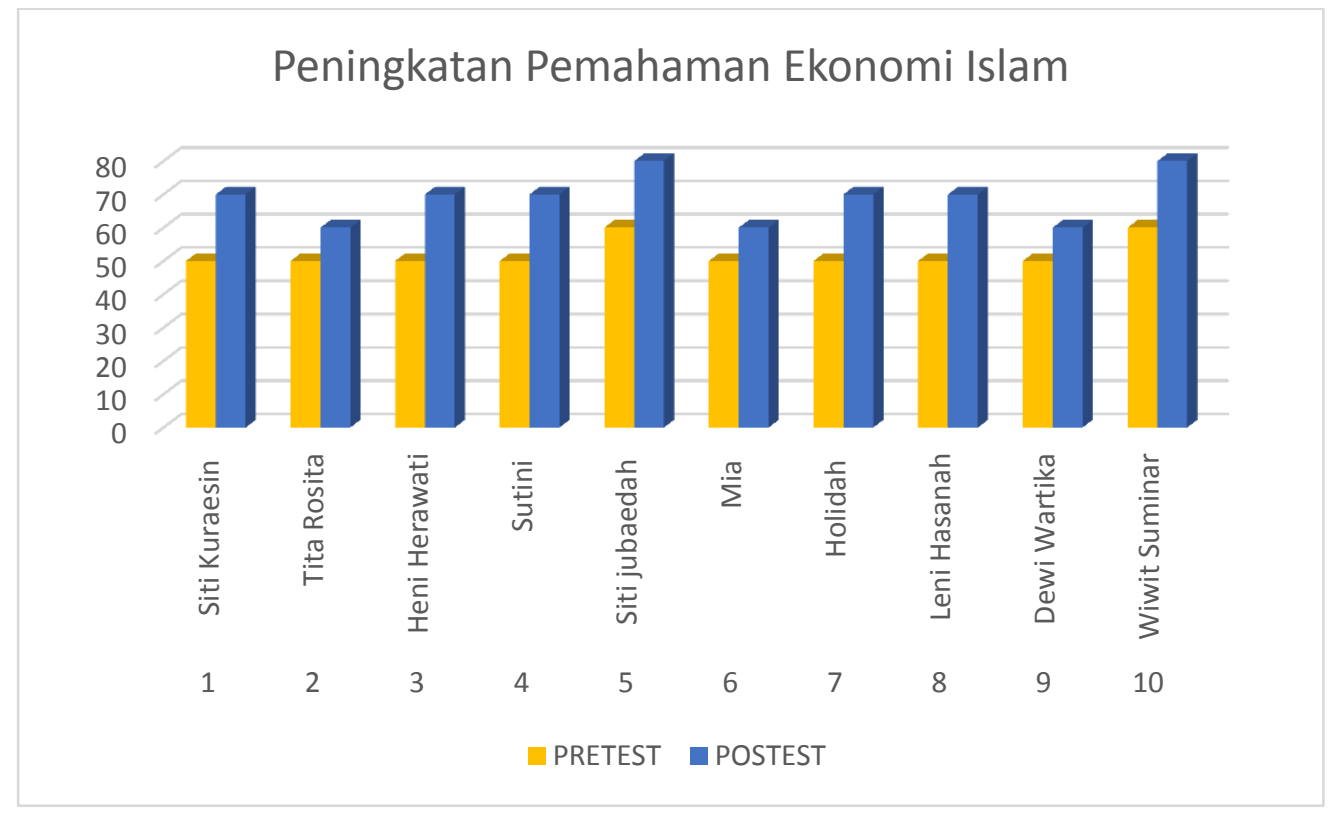

Gambar 5. Peningkatan Pemahaman Ekonomi Islam 
Pemahaman mengenai sistem ekonomi syariah mengalami peningkatan yang cukup terlebih mengenai hukum pinjam meminjam dalam islam. Kini masyarakat paham mengenai hukum meminjam pada rentenir, selain haram hukumnya juga masyarakat dibodohi dengan terus membayar bunga tanpa membayar pokok hutang. Warga belajar juga kini paham akibat dari harta haram yang termakan oleh keluarga akan berdampak pada karakter anak. Jika ingin anak sholeh dan sholehah maka haruslah dinafkahi dengan rejeki yang halal.

\section{Hambatan yang ditemukan dalam ujicoba model kukis}

Beberapa hambatan yang dihadapi dalam penerapan model ini diantaranya adalah :

a. Menurunnya motivasi warga belajar dikarenakan akses menuju lokasi pesantren masih belum memadai.

b. Kesibukan mengurus rumah tangga menjadi kendala dalam pelaksanaan program sehingga beberapa warga belajar tidak melanjutkan program

c. Motivasi untuk memiliki usaha sendiri yang masih sangat rendah sehingga beberapa warga belajar merasa terbebani dengan program ini

d. Rasa tidak percaya diri membuat warga belajar mundur untuk mencoba memasarkan produk hasil karya mereka.

e. Warga belajar lebih memilih untuk melakukan produksi dan mendapatkan upah tanpa memikirkan pemasaran sehingga jiwa entepreneur belum melekat pada warga belajar.

\section{Upaya yang dapat dilakukan untuk mengatasi hambatan dalam ujicoba model kukis.}

a. Mengidentifikasi warga belajar yang siap untuk membangun usaha tanpa paksaan dari pihak manapun sehingga menumbuhkan rasa memiliki terhadap bidang usaha yang ditekuni.

b. Kelompok usaha ini baru pada tahap produksi, dan proses pemasaran dilakukan dengan menjalin kerjsama dengan pihak lain seperti lope-lope craft dan d'narra kitchen.

\section{KESIMPULAN}

Penerapan model Kukis di lingkungan pondok pesantren ini dapat dikatakan berhasil karena terjadi peningkatan dari segi penghasilan dan pemahaman warga belajar. Namun keberhasilan yang dicapai masih belum optimal. Model Kukis terdiri dari beberapa tahap yaitu :

a. Level 1

Socialization

Selecting the members

Filling application form

Grouping the members according to the individual interest

b. Level 2

Accessing clients according to their interest

Choosing approppriate material

Determining the process and media for learning

Projecting outcomes

c. Level 3

Training in specific skills

Mentorship once a week

Strengthening religious values

Entrepreneurship and leadership training 


\section{d. Outcome}

\section{Better bussines skills}

Increased incomes

Product production

Peningkatan penghasilan rata-rata sebesar $18 \%$ yaitu Rp. 255.000 per warga belajar selama 1 bulan memulai usaha menunjukkan adanya keberhasilan penerapan model Kukis meskipun belum optimal. Pemahaman warga belajar juga mengalami peningkatan rata-rata sebesar $33 \%$.

Hambatan yang ditemukan dalam ujicoba model kukis. Beberapa hambatan yang dihadapi dalam penerapan model ini diantaranya adalah :

a. Menurunnya motivasi warga belajar dikarenakan akses menuju lokasi pesantren masih belum memadai.

b. Kesibukan mengurus rumah tangga menjadi kendala dalam pelaksanaan program sehingga beberapa warga belajar tidak melanjutkan program

c. Motivasi untuk memiliki usaha sendiri yang masih sangat rendah sehingga beberapa warga belajar merasa terbebani dengan program ini

d. Rasa tidak percaya diri membuat warga belajar mundur untuk mencoba memasarkan produk hasil karya mereka.

e. Warga belajar lebih memilih untuk melakukan produksi dan mendapatkan upah tanpa memikirkan pemasaran sehingga jiwa entepreneur belum melekat pada warga belajar.

Upaya yang dapat dilakukan untuk mengatasi hambatan dalam ujicoba model kukis.

a. Mengidentifikasi warga belajar yang siap untuk membangun usaha tanpa paksaan sehingga menumbuhkan rasa memiliki terhadap bidang usaha yang ditekuni.

b. Kelompok usaha ini baru pada tahap produksi, dan proses pemasaran dilakukan dengan menjalin kerjsama dengan pihak lain seperti lope-lope craft dan d'narra kitchen.

\section{DAFTAR PUSTAKA}

Tobirin (2013). Formalitas dan Simbolisasi Politik Pemberdayaan Masyarakat dalam Pengentasan Kemiskinan Di Pedesaan. Jurnal Masyarakat, Kebudayaan, dan Politik. Vol. 26-No. 4/2013-10 (265-275). Tersedia [online]: journal.unair.ac.id/filerPDF/mkp21fcf0feb6full.pdf.

Madjid, dkk. (2015). Pengaruh Program Nasional Pemberdayaan Masyarakat (PNPM) Mandiri Perkotaan terhadap Tingkat Kemiskinan di Kota Kotamobagu. Jurnal Berkala Ilmiah Efisiensi. Volume 15 No. 04 Tahun 2015.

Anwas. (2014). Pemberdayaan Masyarakat di Era Global. Alfabeta: Bandung

Daulay, Harmona. (2006). Pemberdayaan Perempuan: Studi Kasus Pedagang Jamu di Geding Johor Medan. Jurnal Harmoni Sosial, Volume I Nomor I, September 2006.

Martono, Nanang. (2011). Sosiologi Perubahan Sosial: Perspektif Klasik, Modern, Posmodern, dan Poskolonial. Rajawali Press: Jakarta.

Novian, Budhy. (2010). Sekilas Tenang Pemberdayaan Perempuan. Artikel Sanggar Kegiatan Belajar Kota Pangkalpinang, Kepulauan Bangka Belitung. 
Depdiknas. (2003). Kamus Besar Bahasa Indonesia, Edisi Ketiga, Jakarta: Penerbit Balai Pustaka.

Koentjaraningrat. (2009). Manusia dan Kebudayaan di Indonesia. Djambangan. Jakarta. Longman.

Buchari, Alma. (2006). Kewirausahaan. Bandung: Alfabeta.

Kasmir. (2007). Kewirausahaan. Jakarta: PT Raja Grafindo Persada.

Suryana. (2003). Kewirausahaan: Pedoman Praktis,Kiat dan Proses Menuju Sukses. Edisi Revisi. Jakarta: Salemba Empat. 